\title{
RESEARCH ARTICLE \\ Seasonal and Spatial Water Pollution Status at The Rivers Estuaries in Cirebon Region
}

Izhamil Hidayah ${ }^{1,2}$, Hedi Indra Januar², Dwiyitno Dwiyitno², and Nining Betawati Prihantini ${ }^{\text {* }}$

\begin{abstract}
OPEN ACCESS
${ }_{1}^{1}$ Departement of Biology, Faculty of Mathematics and Natural Sciences, Universitas Indonesia, Depok, Indonesia 16424

${ }^{2}$ Research Center for Marine and Fisheries Product Processing and Biotechnology, JI. Petamburan VI, Jakarta, Indonesia 10260

${ }^{*}$ Corresponding Author:

nining@sci.ui.ac.id

Received: 30 September 2020

Accepted: 28 June 2021

Published: 9 August 2021

o Squalen Bulletin of Marine and Fisheries Postharvest and Biotechnology, 2021. Accreditation Number: 148/M/KPT/2020. ISSN: 2089-5690, e-ISSN: 2406-9272. doi: $10.15578 /$ squalen. 505
\end{abstract}

\begin{abstract}
Cirebon has 18 rivers that flow into the Java Sea. The Cirebon rivers play an important role in several sectors such as industrial, agriculture, household, and also aquaculture. The increasing anthropogenic activities, may have affected the health and quality of the Cirebon rivers and the surrounding area. This study aimed to determine the water pollution level of Cirebon rivers based on the Storage and Retrieval (STORET) and Pollution Index approaches. The study was conducted at seven different rivers located in the districts (kabupaten) and municipals (kotamadya) of Cirebon. The observation was performed during the end of the west monsoon (March 2019) as well as the beginning (July 2019) and the end of the east monsoon (November 2019). The STORET score of the Cirebon district rivers were between -10 and -20 , which is categorized as lightly to moderately polluted. Similarly, most of the Cirebon municipal rivers were moderately contaminated throughout the year (-18 to -30$)$. In contrast, the Pollution Index (PI) values of all observed rivers were between 1.0 to 5.0 which are categorized as lightly polluted.
\end{abstract}

Keywords: Cirebon, river estuaries, STORET, Pollution Index

\section{I ntroduction}

More than 18 rivers flow in the Cirebon region, such as Cisanggarung, Ciwaringin, Cimanis, Cipager, Pekik, and Kalijaga rivers (BPS Cirebon, 2020). Rising population and developing economic activities around the Cirebon rivers have contributed to the increased garbage disposal into the waterbody. Eventually, this anthropogenic pressure may increase the river fertility and affect its ecological conditions (Rositasari, 2011). Monitoring river quality is essential to assure the water quality meets the standards for drinking water, agriculture and aquaculture activities. Hence, some approaches such as the indexing method have been performed to determine the ecological conditions of water environment.

A river is a water drainage channel that contain natural and/or artificial water, starting from the upstream to the estuary (National Government Regulations of Republic Indonesia No. 38 of 2011). Human waste causes changes in physical, chemical, and biological factors in waters that worsen the quality of the aquatic ecosystem (Sahabuddin, Harisuseno, \& Yuliani, 2014). Recently, many indexing methods have been developed to determine the water quality status, including river water. These methods can be implemented by comparing the monitoring results with the available standards (Altansukh \& Davaa, 2011; Arias, Caraveo, Quintania, Teran, \& Munguia, 2012; De Rosemond, Duro, \& Dube, 2009; Ionus, 2010; Milijasevic, Milanovic, Brankov, \& Radovanovic, 2011; Pejman, Bidhendi, Karbassi, Mehrdadi, \& Bidhendi, 2009). The river's water quality can be assessed using one of two approaches outlined in the Guidelines for Determining Water Quality Status. The Pollution Index (PI) and the Storage and Retrieval (STORET) are the two methods in consideration (Ministry of Environment Decree No. 115 of 2003)

PI is a method to determine the level of water pollution relative to the permitted parameters in the regulation (Nemerow, 1974). Describing the water quality depends on the number of physical substances and bacteriological boundaries (Alves, Teresa, \& Nabout, 2014). The National Sanitation Foundation of the United States (NSF) created a major and widely used Water Quality Index (WQI) in 1970. Lumb, Halliwell, and Sharma (2006) used it to establish the nine significant limits that represent the water quality status. 
In comparison, the STORET method describes the water quality status by comparing water quality data to the appropriate standard following its designated uses (Ministry of Environment Republic Indonesia, 2003). WQI and STORET methods have been used by the United States of Environmental Protection Agency (US-EPA) to monitor the water quality based on a repository data. Based on these methods, the USEPA framework classifies the water quality into four classes (Saraswati, Sunyoto, Kironoto, \& Hadisusanto, 2014).

Supenah, Widiastuti, and Priyono (2015) have studied the water quality of the Condong river in Cirebon using the STORET index. The study showed that the wastewater effluent from the textile and garment industrial area (Batik) heavily contaminated the river. Their research suggested to decrease pollution load and environmental harm in order to protect water quality in Cirebon. However, a simultaneous water quality assessment in the majority of rivers in the Cirebon region are still limited. The present study aimed to determine and compare the water quality of seven Cirebon rivers using the STORET and the PI approaches.

\section{Material and Methods}

\section{Material}

The observations of water quality at Cirebon rivers were carried out three times in two different seasons to obtain an annual river quality profile. In 2019, samplings were conducted in March (at the end of the west season), July (at the start of the east season), and November (at the end of the east season). One liter of surface water sample was taken at $1 \mathrm{~m}$ depth from each site (Figure 1). Five sampling points, i.e., SC1 (Bangkaderes), SC5 (Cikalong), SC11 (Pekik), SC12 (Condong), and SC13 (Bondet) represented Cirebon district rivers. Meanwhile, those depicted Cirebon municipal rivers were SC6 (Sukalila) and SC8 (Cimanuk). The selected sampling points illustrated rivers across agricultural area that headed to aquaculture and fisheries sites in Cirebon Sea Waters (BPS Cirebon, 2020). The coordinate of each sampling site was recorded with Garmin 585 GPS (Indonesia) and plotted into the Google Earth map using ArcGIS 10.8 software (Indonesia).

\section{Methods}

\section{Water Quality Analysis}

Water quality analysis was performed following the method of Barokah, Ariyani, and Siregar (2017). In brief, the water sample was taken at $1 \mathrm{~m}$ depth from each sampling point using a Nansen $1 \mathrm{~L}$-water sampler. Water samples were contained in a $1 \mathrm{~L}$ polyethylene (PE) bottle and were maintained at $4{ }^{\circ} \mathrm{C}$ using an ice cube in a cool box. The salinity, temperature, $\mathrm{pH}$, and DO were measured in situ using Atago portable refractometer, Hanna HI 98107 pH-meter (UK), and HACH HQ40D DO-meter (USA). Nutrient analyses (nitrate, ammonia, and phosphate) were performed using HACH DR-890 analysis kit and a colorimeter (USA). The water samples preservation procedure followed the American Public Health Association (APHA) method (2005).

\section{Data Analysis}

Data on water quality was calculated to determine the level of river contamination. There are two

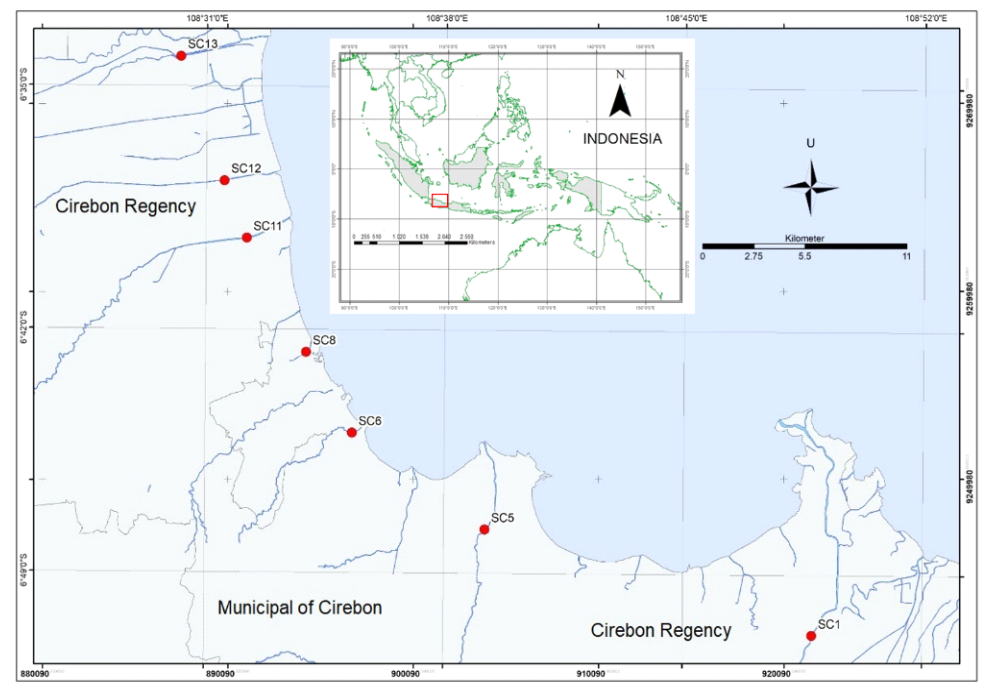

Figure 1. Map of the research location and sampling stations. 
Table 1. STORET Index scoring assurance of water quality status (Canter, 1977)

\begin{tabular}{|c|c|c|c|c|}
\hline \multirow{2}{*}{$\begin{array}{c}\text { Number of } \\
\text { tests }\end{array}$} & \multirow{2}{*}{ Score } & \multicolumn{3}{|c|}{ Parameters } \\
\hline & & Physics & Chemistry & Biology \\
\hline \multirow{3}{*}{$<10$} & Maximum & -1 & -2 & -3 \\
\hline & Minimum & -1 & -2 & -3 \\
\hline & Average & -3 & -6 & -9 \\
\hline \multirow{3}{*}{$>10$} & Maximum & -2 & -4 & -6 \\
\hline & Minimum & -2 & -4 & -6 \\
\hline & Average & -6 & -12 & -18 \\
\hline
\end{tabular}

Table 2. US-EPA STORET Index scoring framework on contamination status (EPA, 2002)

\begin{tabular}{clll}
\hline Class & \multicolumn{1}{c}{ Criteria } & Score & Quality Status \\
\hline A & $\begin{array}{l}\text { Very good } \\
\text { condition }\end{array}$ & 0 & Good condition \\
B & Good condition & -1 to -10 & Lightly polluted \\
C & $\begin{array}{l}\text { Moderately good } \\
\text { condition }\end{array}$ & -11 to -30 & $\begin{array}{l}\text { Moderately } \\
\text { polluted }\end{array}$ \\
D & Bad condition & $\geq-31$ & Heavily polluted \\
\hline
\end{tabular}

Table 3. Pollution score and status of pollution index based on the Ministry of Environment Decree No. 115 of 2003

\begin{tabular}{ll}
\hline \multicolumn{1}{c}{ Value } & \multicolumn{1}{c}{ Water Pollution Status } \\
\hline $0 \leq \mathrm{PI} \leq 1.0$ & Good condition \\
$1.0 \leq \mathrm{PI} \leq 5.0$ & Lightly polluted \\
$5.0<\mathrm{PI} \leq 10$ & Moderately polluted \\
$\mathrm{PI} \geq 10$ & Heavily polluted \\
\hline
\end{tabular}

techniques for determining water quality, i.e., the STORET and the PI indexes. The STORET index was calculated by comparing the water quality data with the standard published by the Indonesian Ministry of Environment (Ministry of Environment Decree No. 115 of 2003). Evaluation of the water quality status was performed according to the scoring framework of the US EPA (Ministry of Environment Republic Indonesia, 2003).

Based on purpose, water quality standard is categorized into four classes: Class I (drinking water); Class II (infrastructure, recreation, cultivation of freshwater fish, livestock, irrigation); Class III (freshwater fish farming, animal husbandry, irrigation); and Class IV (irrigation). In the event that the river class has not been determined, the water quality standard is considered subject to the Class II setting (National Government Regulations of Republic
Indonesia No. 22 of 2021). The following is an equation for calculating the PI value.

PI: Pollution Index; Ci: concentration of water quality parameters i; Lij: concentration of water quality parameters I stated in the water quality standard; m: maximum; r: average

\section{Results and Discussion}

\section{Physicochemical of River Water}

Physicochemical parameters measured in this study were water $\mathrm{pH}$, dissolved oxygen (DO), ammonia, nitrate, and phosphate. Water $\mathrm{pH}$ is an important parameter for the aquatic ecosystem because most of the aquatic biota is sensitive to changes in $\mathrm{pH}$ (Effendi, $2003)$. River water acidity $(\mathrm{pH})$ is closely related to carbon dioxide, in which the higher the $\mathrm{pH}$ value, the lower the carbon dioxide level (Mackereth, Heron, \& Talling, 1989). The water $\mathrm{pH}$ values in the selected Cirebon rivers at three different sampling interval were ranging between 7.20 to 7.80 (Figure 2). The Kruskal Wallis test indicated that the seasonal variation of the sampling stations influenced the $\mathrm{pH}$ value $(p<0.05)$, however the different location did not $(p>0.05)$. These results indicate that the Cirebon rivers' water $\mathrm{pH}$ met the Class II water quality standards (National Government Regulations of Republic Indonesia No. 22 of 2021). According to the US-EPA (2021), the optimal $\mathrm{pH}$ to support aquatic organism is ranging between 6.5 to 8.0 .

DO is the amount of oxygen that is present in water. Primary source of oxygen in water comes from diffusion and photosynthesis (Salmin, 2005). The average DO concentrations in the Cirebon district rivers were varied from 0.45 to $6.83 \mathrm{mg} / \mathrm{L}$. The Kruskal Wallis test indicated that the seasonal variation and the different location of the sampling stations did not influence the DO value $(p>0.05)$. Meanwhile, those in the Cirebon municipal rivers were between 0.13 to 9.32 $\mathrm{mg} / \mathrm{L}$ (Figure 3). Several sampling stations showed DO values less than the minimum requirement of DO level $(<4 \mathrm{mg} / \mathrm{L})$ (National Government Regulations of the Republic of Indonesia No. 22 of 2021). The rivers in the municipal area that showed low DO values were SC6 (Sukalila River) and SC8 (Cimanuk River). Similarly, district rivers with low DO values were SC11 (Pekik River), SC12 (Condong River), and SC13 (Bondet River). $\mathrm{SC} 1$ and $\mathrm{SC} 5$ exhibited $\mathrm{DO}$ values $>4$ $\mathrm{mg} / \mathrm{L}$. 


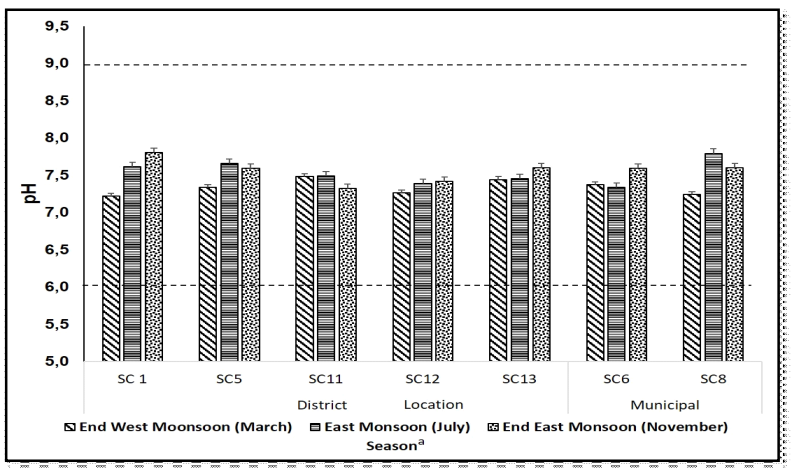

Note: The value between two dash lines indicates the $\mathrm{pH}$ of water meet the standard based on the National Government Regulations of Republic Indonesia No. 22 of 2021

Figure 2. Profiles of water $\mathrm{pH}$ in Cirebon Rivers.

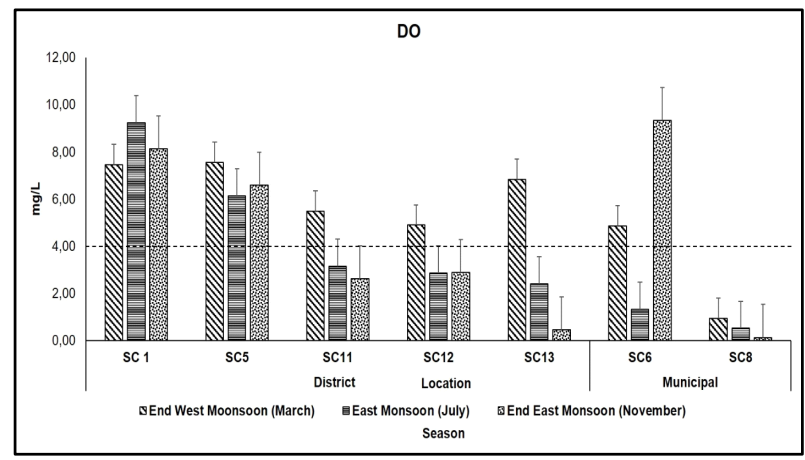

Note: The value above the dashed line indicates the DO of water meet the minimum standards $(>4 \mathrm{mg} / \mathrm{L})$ based on the National Government Regulations of Republic Indonesia No. 22 of 2021

Figure 3. Profiles of DO at Cirebon Rivers.

According to Effendi (2003), the DO content in water is influenced by the decomposition of organic matter and the oxidation of inorganic materials. The highest concentration of DO in the observed district rivers was due to the heavy currents in this area (Gurning, Rochaddi, \& Widada, 2016). The low DO levels at some stations may indicate the domination of pollution by organic matters in the river. Buchari, Arka, Putra, and Dewi (2001) stated that if there are excessive organic resources that contaminate water bodies, the dissolved oxygen will be devoured to decompose it. Hence, the dissolved oxygen content in the water may drop to a low amount. Furthermore, according to Martinez and Galera (2011), DO plays an important role for water-living organisms. Plankton, fish respiration, and microbial decomposition demand enormous amounts of oxygen (Boyd, Torrans \& Tucker, 2017) that potentially causes daily oxygen balance disorder. The absorption of dissolved oxygen in the water is also caused by the death and decomposition of algae and submerged plants known as Carbonaceous Biochemical Oxygen Demand
(CBOD). This process can cause fish and other aquatic organisms with inadequate quantities of dissolved oxygen (Minnesota Pollution Control Agency, 2009).

The ammonia concentration in the observed district and municipal rivers were between 0.09 to 0.29 and between 0.07 to $10.13 \mathrm{mg} / \mathrm{L}$ (Figure 4), respectively. The Kruskal Wallis test indicated that the seasonal variations and the different locations of the sampling stations did not influence the ammonia concentration $(p>0.05)$. Based on the national standard, the maximum tolerable concentration of ammonia for class II water is $0.2 \mathrm{mg} / \mathrm{L}$ water (National Government Regulations of Republic Indonesia No. 22 of 2021). Thus, the water quality of the observed rivers is categorized as highly polluted by ammonia. The SC8 station (Cimanuk River) showed the highest ammonia concentration, ranging from 4 to $10 \mathrm{mg} / \mathrm{L}$. The ammonia pollution in rivers may originate from natural processes and human activities such as household, industrial, and agricultural wastes (Effendi, 2003). The Cimanuk Watershed region serves as the primary drainage system for agriculture, fisheries, and clean water supplies for the Cirebon and Indramayu areas (Nurrohman, Widyastuti, \& Suprayogi 2018). The Cimanuk river is also channeled through the agricultural areas of Kesambi and Kejapan (BPS Cirebon, 2020). The development of the agricultural area has created problems related to chemical fertilizers used to increase agricultural productivity. The leather processing industry in the upstream area has also contributed to domestic waste in the Cimanuk river (Sutriati, 2011).

Nutrients, such as nitrates, are important components for the sustainability of ecosystem function. Nitrate is a nitrogen component commonly found in the waters (Pasisingi, Pratiwi, \& Krisanti, 2014). The nitrate contents in the Cirebon river sampling stations were ranging from 0.01 to $0.58 \mathrm{mg} /$ L (Figure 5). The Kruskal Wallis test indicated that the seasonal variation influenced the nitrate contents in the sampling stations $(p<0.05)$, however the different location did not $(p>0.05)$. In general, the range of nitrate contents in this study met the permitted maximum standards limit $(<10 \mathrm{mg} / \mathrm{L}$ ) (National Government Regulations of Republic Indonesia No. 22 of 2021). Variations of nitrogen content across the sampling stations were possibly influenced by the different nutrient inputs from the surrounding municipal activities. Pasisingi et al., 2014) stated that river is often transporting waste from mainland that may influence and change the states of the environment. The nitrate content of the district rivers were higher during the end of west monsoon compared to that of the end of east monsoon. This is might be due to run-off carrying nitrate from the mainland during the end of west monsoon. 


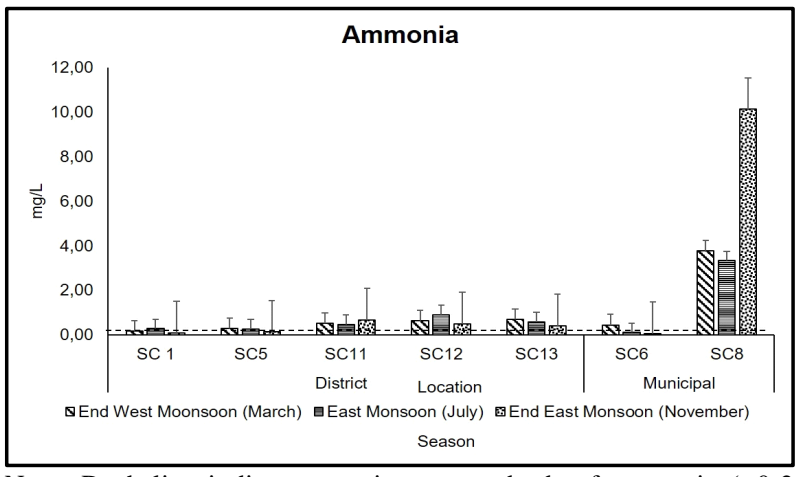

Note: Dash line indicates maximum standards of ammonia $(<0$. $\mathrm{mg} / \mathrm{L}$ ) based on the National Government Regulations of Republic Indonesia No. 22 of 2021

Figure 4. Profiles of Ammonia at Cirebon Rivers.

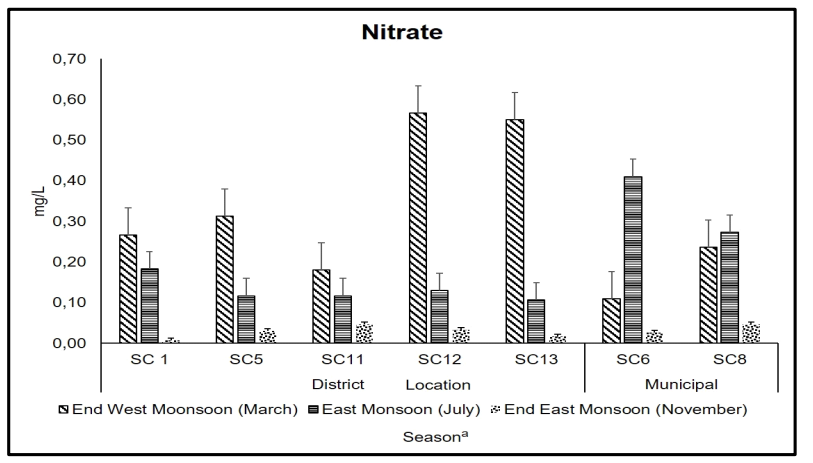

Note: The maximum standards of nitrate-based on National Government Regulations of Republic Indonesia No. 22 of 2021 is $<10 \mathrm{mg} / \mathrm{L}$

Figure 5. Profiles of Nitrate at Cirebon Rivers.

Phosphate is an essential nutrient for algae that may also affect water fertility. Based on our study, the concentrations of phosphate in the observed district rivers exceeded the threshold value (max. $0.2 \mathrm{mg} / \mathrm{L}$ ) (National Government Regulations of Republic Indonesia No. 22 of 2021). Total phosphate concentrations in both district and municipal rivers were 0.23 to $1.79 \mathrm{mg} / \mathrm{L}$ and 0.32 to $8.70 \mathrm{mg} / \mathrm{L}$ (Figure $6)$, respectively. The Kruskal Wallis test indicated that the seasonal variation and the different location of the sampling stations did not influence the phosphate concentration $(p>0.05)$. In general, phosphate value in natural waters should be less than $1 \mathrm{mg} / \mathrm{L}$ (Boyd, 1988). According to Anhwange, Agbaji, and Gimba (2012), the maximum recommended level of phosphate for rivers and waters is $0.1 \mathrm{mg} / \mathrm{L}$. Water with a phosphate value of more than $0.1 \mathrm{mg} / \mathrm{L}$ is categorized as eutrophic water. Eutrophication is a type of water pollution produced by excessive nutrients, causing the uncontrolled development of aquatic plants and phytoplankton (Simbolon, 2016). Eutrophic waters can trigger phytoplankton bloom (Kadim, Pasisingi \& Paramata, 2017).
Phosphate is the least abundant of the nutrients needed in substantial quantities by phytoplankton in freshwaters. It is the principal nutrient that may restrict the growth of phytoplankton (Schindler, 1977). It can limit or co-limit phytoplankton bloom in estuarine and marine environments with high nitrogen inputs (Rudek, Paerl, Mallin, \& Bates, 1991; Fisher, Peele, Ammerman \& Harding, 1992).

\section{Analyses of STORET and Pollutant I ndex}

(STORET) and (PI) are two approaches used to assess the quality of river water (Ministry of Environment Decree No. 115 of 2003). The first has been commonly used to evaluate water quality status (Barokah et al., 2017; Triawan, Harlianto, \& Nesbah, 2018). This research used five parameters for calculating the STORET index, i.e., $\mathrm{pH}, \mathrm{DO}$, nitrate, ammonia, and phosphate.

The selected rivers in this study are categorized as moderately polluted based on the US-EPA STORET Index (Table 2). The different location of the sampling stations influenced the STORET index $(p<0.05)$, however the seasonal variation did not $(p>0.05)$. Rivers in the Cirebon districts that have a high STORET score were SC11 (Pekik River), SC12 (Condong River), and SC 13 (Bondet River). Whereas, that in the municipal of Cirebon was SC 8 (Cimanuk River) (Figure 7).

SC11 (Pekik River), SC12 (Condong River), and SC 13 (Bondet River) are located on the north side of the Cirebon district. The pollution sources in this area were due to the anthropogenic pressure from agricultural areas (Jamblang) and densely populated areas (Tangkil, Gunung Jati, and Samadikun) (BPS 2020). These anthropogenic activities affected the DO, ammonia, and phosphate parameters to negatively increase the STORET score (-20) - (-30). These results were in line with the previous study on the STORET index of -31 in Condong River (Cirebon District) (Supenah et al., 2015).

Another method to determine the quality of water is PI (Tanjung, Hamuna, \& Alianto, 2019). The difference between the STORET and PI methods is the determination of the value or score that is used as a reference. The STORET method uses a value scale of -31 to 0 , while PI's uses a score of 0 to 10 (Sahabuddin et al., 2014). The analysis principles of both methods are also different. The STORET index is based on the weighted scoring of multiple parameters that are considered significant. Meanwhile, PI provides a single score for the observed parameters to interpret water quality status (Dunca, 2018). In the current study, the PI values of the observed rivers were less than 5.0 (Figure 8). Based on the national standard, 


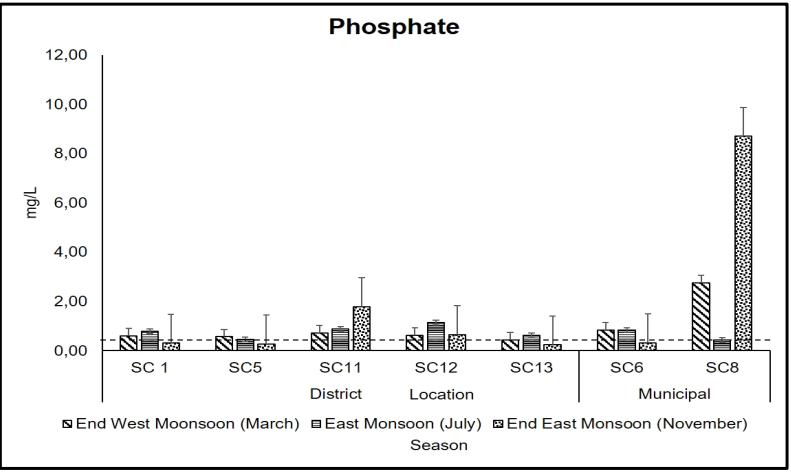

Note: Dash line indicates maximum standards of phosphate $(0.2$ $\mathrm{mg} / \mathrm{L}$ ) based on the National Government Regulations of Republic Indonesia No. 22 of 2021

Figure 6. Profiles of Phosphate at Cirebon Rivers.

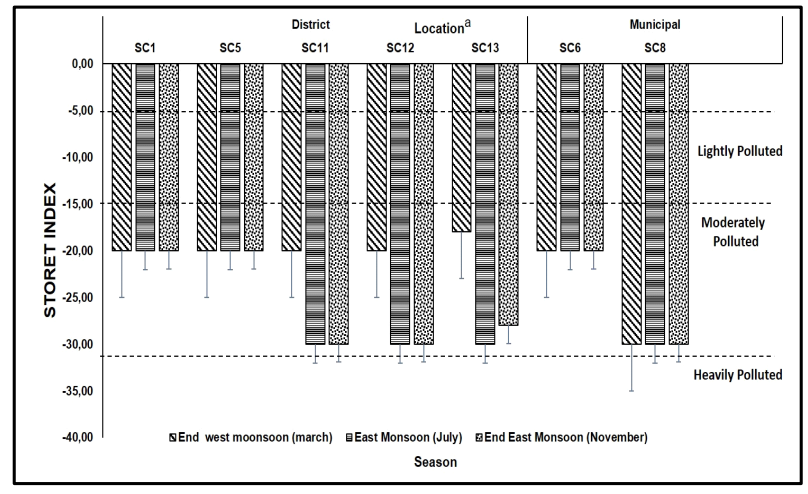

Note: Dash line indicates the classification of STORET Index based Ministry of Environment Decree No. 115 of 2003

Figure 7. Result of STORET Index of the rivers at Cirebon region.

the values between 1.0 to 5.0 is categorized as lightly polluted (Ministry of Environment Decree No. 115 of 2003). The Kruskal Wallis test indicated that the variations of seasons and locations did not influence the Cirebon river pollution index $(p>0.05)$.

The results from the current study showed that the STORET method calculated a higher pollution level status than PI. These findings were also in accordance
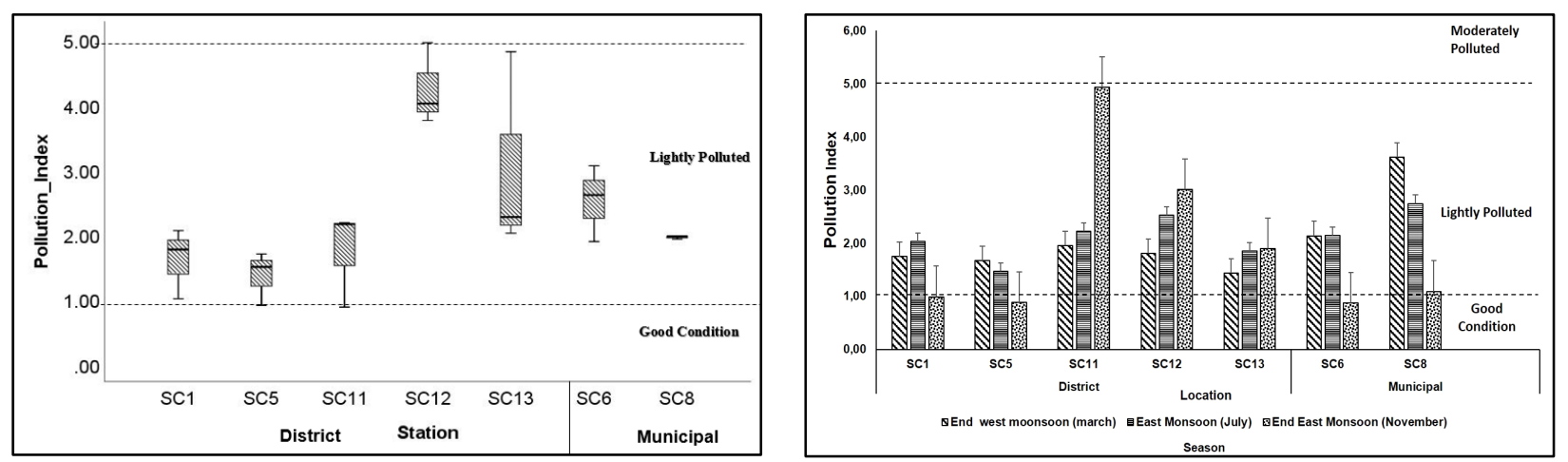

Note: dash line indicates the classification of Pollution Index based on Ministry of Environment Decree No. 115 of 2003

Figure 8. Result of spatial (a) and temporal (b) Pollution Index of the rivers at Cirebon Rivers. with previous studies (Yusrizal, 2015; Barokah et al., 2017; Jubaedah, Hariyadi, Muchsin \& Kamal, 2015). The PI results were inconsistent compared to those of the STORET method.

The discrepancies between STORET and PI results can be explained as follow. The STORET index was calculated based on the maximum, minimum, and mean values from the data of several water quality samples. The more water quality parameters that are measured, the more monitoring parameters that do not meet the quality standards (from the maximum and minimum parameter values). Accordingly, the more often these parameters do not meet the threshold, the worse the water quality status (Saraswati et al., 2014). In PI, there is no sub-index score scheme or definitive (subjective) score per parameter. The most significant parameter is calculated on the basis of the largest ratio of concentration to the quality standard. In contrast to STORET with multiple water quality parameters, $\mathrm{PI}$ is not sensitive enough to distinguish water quality status classes. This is because the PI scoring method only consider single parameter with maximum $\mathrm{Ci} / \mathrm{Lij}$, but not the average of all water quality parameters.

Results from our study indicated that Cirebon rivers are categorized as polluted rivers, that may affect the coastal ecosystem. Continuous improvement is thus needed to increase river water quality in the Cirebon area. Improved river water quality will impact the quality of Cirebon sea waters and the safety of aquatic organisms.

\section{Conclusion}

Seasonal assessment of the water quality from several Cirebon river estuaries using the STORET and the PI methods showed a different result. Based on the STORET index, the Cirebon rivers was categorized as moderately polluted (score of -18 to -30 ). Meanwhile, the water quality of rivers in Cirebon region was categorized as lightly polluted based on the PI value. The polluted condition of rivers in Cirebon region 
needs attention by all stakeholders. The river condition possibly influence the Cirebon sea waters' condition and affect the safety and quality of some fishery commodities.

\section{Acknowledgments}

This study was financed by the Indonesian Research and Development Center for Marine and Fisheries Product Processing and Biotechnology DIPA No. SP. DIPA-032.12.2.403835/2019. Our gratitude goes to Sri Iswani, Anggit Prabawati, and Rina Rustiani at the Indonesian Research Center for Marine and Fisheries Product Processing and Biotechnology, who helped us during sampling activities and preparation. We thank the Indonesian Fish Quarantine and Inspection Agency (FQIA) in Cirebon for their assistance during sampling activities.

\section{References}

Anhwange, B. A., Agbaji, E. B., \& Gimba, E. C. (2012). Impact assessment of human activities and seasonal variation on river benue,within Makurdi Metropolis. Journal Science and Technology 2: 248-254

APHA (American Public Health Association). (2005). Standard method for the examination water and wastewater (15 th Edition) (pp.1134). Washington. D.C: American Public Health Association.

Altansukh, O., \& Davaa, G. (2011). Application of index analysis to evaluate the water quality of the Tuul River in Mongolia. Journal of Water Resource and Protection 2011(3), 398414. doi: 10.4236/jwarp.2011.36050

Alves, M. T. R., Teresa, F. B., \& Nabout, J. C. (2014). A global scientific literature of research on water quality indices: trends, biases and future directions. Acta Limnologica Brasiliensia, 26(3), 245-253. doi: 10.1590/S2179-975X2014 000300004

Arias, H. R., Caraveo, M. C., Quintania, R. M., Teran, R.A.S, \& Munguia, A.P. (2012). An overall Water Quality Index (WQI) for man-made aquatic reservoir in Mexico. International Journal of Environtmntal Research and Public Health,9, 9(5), 1687-16981. doi: 10.3390/ijerph9051687

Barokah, G. R., Ariyani, F., \& Siregar, T. H. (2017). Comparison of STORET and pollution index method to assess the environmental pollution status: a case study from Lampung Bay, Indonesia. Squalen Bulletin of Marine and Fisheries Postharvest and Biotechnology, 12(2), 67-74. doi: 10.15578/ squalen.v12i2.287.

Boyd, C. E. (1988). Water quality in warmwater fish ponds. Auburn University.

Boyd, C. E., Torrans, E. L., \& Tucker, C. S. (2017). Dissolved oxygen and aeration in ictalurid catfish aquaculture. Journal of World Aquaculture Society, 49(1): 7-70. doi: 10.1111/ jwas. 12469

BPS [Badan Pusat Statistik] Kabupaten Cirebon. (2020). Kabupaten Cirebon dalam angka. CV Munjul Jaya
Buchari, Arka, I.W., Putra, K.G.D., \& Dewi, I (2001). Kimia Lingkungan. Jakarta (ID): DJPT. 237 pp.

Canter, L.W. (1977). Environmental Impact Assesment, University of Oklahoma (pp. 86-118). New York: McGrawHill Book Company.

De Rosemond, S., Duro, D. C., \& Dubé, M. (2009). Comparative analysis of regional water quality in Canada using the Water Quality Index. Environmental Monitoring and Assessment, 156(1-4), 223. doi: 10.1007/s10661-008-0480-6

Dunca, A. M. (2018). Water pollution and water quality assessment of major transboundary rivers from Banat (Romania). Journal of Chemistry, 2018, 1-8. doi:10.1155/ 2018/9073763

Effendi, H. (2003) Telaah kualitas air bagi pengelolaan sumber daya dan lingkungan perairan. Yogyakarta: Kanisius.

US-EPA (United States Environmental Protection Agency). (2002). Water quality criteria. Mid-Atlantic Integrated Assessment (MAIA) Estuaries (pp. 595). USA : Ecological Research Series Washington

Fire, S. E., \& Van Dolah, F. M. (2012). Marine biotoxins: emergence of harmful algal blooms as health threats to marine wildlife. Publications, Agencies and Staff of the U.S. Department of Commerce. 553.

Fisher, T.R., Peele, E.R., Ammerman, J.W \& Harding, W. (1992). Nutrient limitation of phytoplankton in Chesapeakegay. Marine Ecology Progress Series, 82: 51-63.

Gurning, R.H., Rochaddi, B., \& Widada, S. (2016). Pengaruh arus terhadap muatan padatan tersuspensi di muara sungai dan sekitar perairan kesunean, Cirebon. Jurnal Oseanografi, 5(4), 512-522.

Ionus, O. (2010). Water quality index-assessment method of the Motru river water quality (Oltenia, Romania). Annals of the University of Craiova. Series Geography/Analele Universitatii din Craiova. Seria Geografie, 13.

Jubaedah, D., Hariyadi,S., Muchsin, I., \& Kamal, M. (2015). Water quality index of floodplain river Lubuk Lampam South Sumatera Indonesia. International Journal of Environmental Science and Development, 6(4): 252-258. doi: 10.7763/ IJESD.2015.V6.600

Kadim, M. K., Pasisingi, N., \& Paramata, A. R. (2017). Kajian kualitas perairanTeluk Gorontalo dengan menggunakan metode STORET.Depik, 6(3): 235-241. doi:10.13170/depik. 6.3 .8442

Lumb, A., Halliwell, D., \& Sharma, T. (2006). Application of water quality index to monitor water quality: a case of the Mackenzie river basin, Canada. Environmental Monitoring and Assessment, 113,411-429. doi:10.1007/s10661-0059092-6

Martinez, F. B., \& Galera, I. C. (2011). Monitoring and evaluation of the water quality of Taal Lake, Talisay, Batangas, Philippines. Academic Research International, 1(1), 229.

Mackereth, F. J. H., Heron, J., \& Talling, J. F. (1989). Water analysis: some revised methods for limnologists (Second Impression).

Ministry of Environment Republic Indonesia. (2003). Ministry of Environment decree number 115 of 2003 about the guidelines for determination of water quality status. Jakarta (ID). 
Minnesota Pollution Control Agency. (2009). Low dissolved oxygen in water causes, impact on aquatic life - an overview. Water Quality/Impaired Waters 3(24): 1-2

Milijasevic, D., Milanovic, A., Brankov, J., \& Radovanovic, M. (2011). Water quality assesment of the Broska Reka River using the WPI (Water Pollution Index Method). Archives of Biological Sciences, Belgrade, 63(3), 819-824. doi: 10.2298/ ABS1 103819M

National Government of the Republic of Indonesia. (2011). Government regulation number 38 of 2011 concerning River, Jakarta.

National Government of the Republic of Indonesia. (2021). Government regulation number 22 of 2021 concerning the implementation of environmental protection and management, Jakarta.

Nemerow, N. L. 1974. Scientific Stream Pollution Analysis. Scripta Book Co Washington DC.

Nurrohman, A. W., Widyastuti, M., \& Suprayogi, M. (2018). Evaluasi kualitas air menggunakan indeks pencemaran di DAS Cimanuk, Indonesia. Ecotrophic, 13(1), 74-84

Pasisingi, N., Pratiwi, N. T., \& Krisanti, M. (2014). Kualitas perairan sungai cileungsi bagian hulu berdasarkan kondisi fisik-kimia. DEPIK Jurnal Ilmu-Ilmu Perairan, Pesisir dan Perikanan, 3(1), 56-64. doi: 10.13170/depik.3.1.1376

Pejman, A. H., Bidhendi, G. N., Karbassi, A. R., Mehrdadi, N., \& Bidhendi, M. E. (2009). Evaluation of spatial and seasonal variations in surface water quality using multivariate statistical techniques. International Journal of Environmental Science \& Technology, 6(3), 467-476. doi: 10.1007/BF03326086

Rositasari, R. (2011). Karakteristik komunitas Foraminifera di perairan teluk Jakarta. Jurnal Ilmu dan Teknologi Kelautan Tropis 3(2): 100-111.

Sahabuddin, H., Harisuseno, D., \& Yuliani, E. (2014). Analisa status mutu air dan daya tampung beban pencemaran Sungai Wanggu Kota Kendari. Jurnal Teknik Pengairan, 5(1), 1928.

Rudek, J., Paerl, H.W., Mallin, M.A \& Bates, P.W. (1991). Seasonal and hydrological control of phytoplankton nutrient limitation in the lower Neuse River estuary, North Carolina. Marine Ecdogy Progress Series, 75:133-142.

Salmin (2005). Oksigen terlarut (DO) dan kebutuhan oksigen biologi (BOD) sebagai salah satu indikator untuk menentukan kualitas perairan. Oseana, 30(3), 21-26.
Saraswati, S. P., Sunyoto, Kironoto, B. A., \& Hadisusanto. (2014). Assessment of the forms and sensitivity of the index formula PI, STORET, CCME for the determination of water quality status of a tropical stream in Indonesia. Jurnal Manusia dan Lingkungan, 21 (2), 129-142. doi: 10.22146/ jml.18536

Schindler, D.W. 1977. Evolution of phosphorus limitation in lakes. Science 196:260-262. doi: 10.1126/science.195. 4275.260

Simbolon, A. R. (2016). Pencemaran Bahan Organik dan Eutrofikasi di Perairan Cituis, Pesisir Tangerang. Jurnal ProLife: Jurnal Pendidikan Biologi, Biologi, dan Ilmu Serumpun, 3(2), 109-118

Supenah, P., Widiastuti, E., \& Priyono, R. E. (2015). Kajian kualitas air sungai condong yang terkena buangan limbah cair industri batik trusmi Cirebon. Majalah Ilmiah Biologi BIOSFERA: A Scientific Journal, 32(2), 110-118. doi: 10.20884/1.mib.2015.32.2.302

Sutriati, A. (2011). Penilaian kualitas air sungai dan potensi pemanfaatannya: Studi kasus sungai Cimanuk. Jurnal Sumber Daya Air, 7(1),1-17. doi: 10.32679/jsda.v7i1.378

Suwari, Riani, E., Pramudya, B., \& Djuwita, I. (2010). Determination of water quality status of surabaya river water with Storet method and pollution index. Majalah Ilmiah Widya, 27(2),59-63.

Tanjung, R. H. R., Hamuna, B., \& Alianto. (2019). Assessment of water quality and pollution index in coastal waters of Mimika, Indonesia. Journal of Ecological Engineering, 20(2),87-94. doi:10.12911/229989 93/95266

Triawan, D.A., Harlianto, B., \& Nesbah. (2018). Ground water quality characteristics study in coastal area of bengkulu city by using storeT Method: A Cross-Sectional Study. Proceeding 1st International Conference on Chemistry, Pharmacy and Medical Sciences, Bengkulu, 27-28 November 2018, 8, 47-51.

US-EPA (United States Environmental Protection Agency) (2021). National Aquatic Resource Surveys. Indicators: Acidification. USA. Accessed on 27th April 2021

Yusrizal, H. (2015). Efektivitas metode perhitungan STORET, IP dan CCME WQI dalam menentukan status kualitas air Way Sekampung Provinsi Lampung. Jurnal Sains dan Pendidikan 2(1),11-23 